${ }^{13}$ Stroobandt, R, Fagard, R, and Amery, A, American Heart fournal, 1973, 86, 781.

14 Thurston, H, and Swales, J D, Lancet, 1976, 2, 930

15 Beevers, D G, et al, Kidney International, 1976, 8, S181.

16 Woods, J W, et al, New England fournal of Medicine, 1976, 294, 1137.

17 Veterans Administration Cooperative Study Group, fournal of the American Medical Association, 1967, 202, 1028.

18 Veterans Administration Cooperative Study Group, fournal of the American Medical Association, 1970, 213, 1143.

19 Berglund, G, et al, Lancet, 1978, 1, 1.

20 Wilhelmsen, L, British Medical fournal, 1978, 1, 1348.

\section{Is schizophrenia a psychosis or a neurosis?}

Schizophrenia is classed as one of the psychoses; if asked to say which symptoms were chiefly responsible for the incapacity most doctors would probably cite such conventional psychotic manifestations as delusions and hallucinations. These are certainly prominent in the acute stage, but schizophrenia is usually a chronic disorder, and a recent study ${ }^{1}$ suggests that in chronic schizophrenia the symptoms that cause the most handicap and present the most intractable management problems are those usually termed neurotic.

Cheadle and colleagues ${ }^{1}$ studied 190 schizophrenics treated for an average of 12 years mainly in the community (144 had had no admissions in the previous year) and found that worrying, social unease, tension, depression, lack of energy, and irritability were far commoner than delusions and hallucinations. More important, patients with high neurotic scores seemed to have more difficulties with work and social life than those with psychotic symptoms.

The average age of these patients was about 45, but barely a quarter were working, and isolation was common. Most of the men $\left(69^{\circ}\right)$ had never married. Of the women, by contrast, $68 \%$ had married; but over half had later become divorced or separated. Many patients who did not actively complain about isolation seemed to be leading a restricted and unrewarding existence. Thoreau's belief that "most men lead lives of quiet desperation" may not generally be true, but it accurately describes the plight of many schizophrenics.

Cheadle et al seemed surprised by the high prevalence and seriousness of neurotic problems, but perhaps it is not so unexpected. Delusions and hallucinations need not be a major handicap if the patient does not talk about them. "If you can't be sane, try to be discreet" is still sound advice for psychotic patients. Paranoid schizophrenics in particular may appear remarkably "normal" if they keep off their paranoid hobbyhorse and may find little difficulty in staying married and employed. What cannot be so easily hidden is the social incompetence which is evident so often in schizophrenia and which creates such problems in getting and keeping both jobs and friends. These negative symptoms are not only a serious handicap but, unlike the positive ones, they do not readily respond to the neuroleptic drugs which are of such value in reducing the number and frequency of exacerbations.

Taken with other studies showing the poor quality of schizophrenic life,,$^{2.3}$ these findings raise further questions about the appropriateness of "community care" for patients whose main problem is the lack of precisely those social skills which are necessary for living in an ordinary community. Indeed, the whole concept is coming under increasing challenge ${ }^{4}$; critics have suggested that before the mental hospitals are emptied it would have been prudent to find out whether or not the community does, indeed, care. There is a strong possibility that it does not, although Bennett ${ }^{5}$ rightly warns against dogmatism. "A good hospital is better than a poor hostel. ... A good family environment is better than a poor hospital. . . . Universal denunciation of any one type of setting is likely to be harmful. ...."
The study by Cheadle et $a l^{1}$ also fuels another perennial psychiatric controversy-namely, the utility of our concepts of neurosis and psychosis with their different and sometimes competing meanings. Psychosis, in particular, when not synonymous with schizophrenia, is used variously to imply seriousness, an endogenous quality, and the presence of delusions; while neurosis can imply a lesser disorder, an aetiology based on environment or personality, and the preservation of contact with reality. Words so accommodating and flexible are of dubious scientific value. Furthermore, some of these implied meanings are misleading. Amphetamine psychosis has a good prognosis; obsessive compulsive neurosis a bad one. Neurotic behaviour may be a manifestation of organic brain disease, and $\mathrm{Sims}^{6}$ has shown that neurosis has a substantial mortality.

Any symptom requires a context to be of use in diagnosis or treatment. Backache has very different connotations in cancer and influenza. It would be unfortunate if a well-intentioned emphasis on the neurotic symptoms of schizophrenics merely gained them the sort of dismissive attitude which is commonly encountered by the ordinary run of neurotic patients.

${ }^{1}$ Cheadle, A J, Freeman, H L, and Korer, J R, British fournal of Psychiatry, 1078, 132, 221

${ }^{2}$ Brown, G W, Birley, J L T, and Wing, J K, British fournal of Psychiatry, 1972, 121, 241.

${ }^{3}$ Wing, J K, and Creer, C, Schizophrenia at Home. London, Institute of Psychiatry, 1974.

${ }^{4}$ Hawks, D, British fournal of Psychiatry, 1975, 127, 276.

${ }^{5}$ Bennett, D, British fournal of Psychiatry, 1978, 132, 209.

${ }^{6}$ Sims, A, Lancet, 1973, 2, 1072.

\section{Maternal alcohol consumption and birth weight}

The effects of the mother's alcohol consumption on the fetus became known in the early part of this century, ${ }^{1}$ but the subject was then ignored until the description of infants with the "fetal alcohol syndrome." Animal studies had already suggested that intrauterine growth retardation often resulted from chronic exposure to alcohol, ${ }^{5-7}$ but only within the last decade has the subject been resuscitated: for example, Ulleland et al ${ }^{8}$ studied 12 infants delivered to 11 alcoholics and found 10 small for gestational age.

Is there any intake of alcohol that is safe for the fetus? Unfortunately the data so far published have not provided enough detail to answer this question. A prospective study in France ${ }^{9}$ found that women who consumed the equivalent of $400 \mathrm{ml}$ or more of wine a day during pregnancy had a significant excess of perinatal deaths, fetal growth retardation, and low placental weight. The French authors, however, made no attempt to exclude any chronic alcoholics, so that a small group of very heavy drinkers could have biased their results.

Furthermore, results are always confounded by the fact that women who drink tend also to smoke. A prospective study by Little ${ }^{10}$ therefore identified 66 women with an average daily consumption of at least $35 \mathrm{ml}$ of absolute alcohol before conception. For each of these cases they chose three controls, matched for smoking habits: one with a low intake of alcohol (less than $3.5 \mathrm{ml} /$ day) and two with an intermediate intake $(3.5 \mathrm{ml}$ to $34 \mathrm{ml} / \mathrm{day})$. They found a significant negative association between birth weight and the amount of alcohol consumed in late pregnancy. The regression equation indicated that for each $35 \mathrm{ml}$ of absolute alcohol consumed in later pregnancy the mean birth weight would be reduced by $160 \mathrm{~g}$; this estimate, however, was based on only 20 women who drank $35 \mathrm{ml}$ or more at this time. It is curious that in the whole sample of 264 singleton infants only seven $\left(2 \cdot 7^{\circ}\right)$ weighed less than $2500 \mathrm{~g}$.

Only one study, ${ }^{11}$ in the United States, has partitioned the data adequately and examined the incidence of prematurity. 
During pregnancy women were asked about their alcohol consumption and divided into three groups: group 1 (152 deliveries) consisted of women who drank less than once a month; group 2 (128 deliveries) of women who drank at least once a month but did not, on average, exceed $45 \mathrm{ml}$ of absolute alcohol a day; and group 3 (42 deliveries) of women who consumed on average more than $45 \mathrm{ml}$ of absolute alcohol a day. Significantly more infants born to women in group 3 were premature or small for gestational age, but there was no difference in these respects between groups 1 and 2 .

Certainly we cannot be didactic about the effect of moderate alcohol consumption on the fetus. An occasional drink seems unlikely, on present evidence, to affect the infant's birth weight; but a line cannot be drawn between amounts safe and dangerous for the fetus. Collection of data in Britain would be helpful. The French study ${ }^{9}$ indicated that the type of drink might be important: perinatal mortality and growth retardation were more apparent in the infants of women who drank beer than of those who drank wine. Meanwhile obstetricians would be wise to urge women to cut down their alcohol intake once they become pregnant.

1 Green, H G, American fournal of Obstetrics and Gynecology, 1974, 118, 713.

2 Jones, K L, and Smith, D W, Lancet, 1973, 2, 999.

3 Mulvihill, J J, and Yeager, A M, Teratology, 1976, 13, 345.

4 British Medical fournal, 1976, 2, 1404.

Stockard, C R, and Papinicolaou, G N, fournal of Experimental Zoology, 1918, 26, 119.

${ }^{6}$ Bluhm, A, Archiv für Rassen und Gesellschafts Biologie, 1930, 24, 12.

- Pilström, L, and Kiessling, K H, Acta Pharmacologica et Toxicologica, $1967,25,225$.

* Ulleland, C, et al, Pediatric Research, 1970, 4, 474.

${ }^{9}$ Kaminski, M, Rumeau-Rouquette, C, and Schwartz, D, Revue d'Epidemiologie et Medécine Sociale de Santé Publique, 1976, 24, 27.

1" Little, R E, American fournal of Public Health, 1977, 67, 1154.

11 Ouellette, E M, et al, New England fournal of Medicine, 1977, 297, 528.

\section{Hormone receptors in breast cancer}

Various sex steroid hormones are known to bind to receptors in the tumour tissue of some patients with breast cancer; the receptors act as multipliers, concentrating the growth-promoting hormones in the neoplastic tissue and increasing its ability to synthesise RNA and protein. ${ }^{1}$ Cikes $^{2}$ has suggested that these receptors for growth-promoting hormones, whose effect may parallel ectopic hormone production by tumours, may enable neoplastic cells to escape growth control. Receptors for oestrogen, ${ }^{3}$ progesterone, ${ }^{4}$ and androgen ${ }^{5}$ have been identified in human breast cancer by various assay procedures.

Assays of specific steroid receptor proteins make use of the receptors' ability to bind tightly to tritium-labelled steroids. The dextran-coated charcoal method ${ }^{6}$ relies on the ability of charcoal to absorb free steroid, the addition of dextran limiting absorption of steroid-receptor complexes. This method is relatively easy, fast, and sensitive and does not require expensive equipment, but cannot identify the molecular form of the receptor. The sucrose gradient technique ${ }^{7}$ is slow and expensive, but it does distinguish the molecular forms. Other assay methods include agar-gel electrophoresis, ${ }^{*}$ protamine sulphate precipitation, ${ }^{9}$ hydroxyapatite adsorption, ${ }^{10}$ and Sephadex gel filtration. ${ }^{11}$ At present no one assay is ideal, but in terms of simplicity and cost the dextran-coated charcoal method is probably the best.

The proportion of breast cancers that contain oestrogen receptors (ER) varies in reported series from 35 to $85 \%$. The proportion has risen over the years, possibly reflecting technical i mprovements in assays. ${ }^{1}$ Tumour tissue from metastatic sites examined at different stages of the disease has shown little variation from the primary tumour. ${ }^{12}$ The concentration of receptors in ER-positive patients varies over a wide range, ${ }^{13}$ however; and Leclercq and Heuson ${ }^{1}$ have suggested that most, if not all, breast tumours contain receptors, though in some cases their concentration is too low to be detected with the current assays. Many investigators now use an arbitrary minimum concentration of receptors to define ER-positive tumours. The mean concentration of receptors is lower in premenopausal women. ${ }^{14}$

Larger series, including an international review, ${ }^{1516}$ have shown that $60^{\circ}{ }^{\circ}$ of patients with ER-positive breast tumours respond to treatment by hormonal manipulation. In contrast, only $8-16^{\circ}$ " of ER-negative patients respond to similar treatment. ${ }^{1}$ Correlation of ER measurements with clinical variables improves accuracy in predicting this response. ${ }^{1}$

Progesterone receptors (PgR) have been reported in 30-60\% of breast cancers ${ }^{17}$; they occur only in patients who are ERpositive. ${ }^{1}$ Progesterone receptors may therefore indicate an intact ER system, and a finding of both ER and PgR positivity might be expected to correlate closely with hormonal responsiveness. Early data $1 \times 19$ seemed to substantiate this hypothesis, but Leclercq's small study ${ }^{1}$ did not support it and further investigation is needed. Few data are available on the predictive values of androgen receptors (AR), which have been detected in $20-50^{\circ}$ o of breast cancers, ${ }^{1}$ though hormonal responsiveness has been recorded in small numbers of AR-positive patients. ${ }^{5} 20$

Though hormone receptors (and especially ER) have improved our ability to predict hormonal responsiveness in breast cancer, there is still a large unexplained false-positive rate. Some tumours may be composed of a mixed population of receptorpositive and receptor-negative cells; continued growth of negative cells would then lead to hormonal insensitivity. Alternatively, loss of the cells' ability to transfer the cytoplasmic oestrogen-receptor complex to the nucleus may account for false-positives; the new generation of assays for nuclear receptors will therefore be important.

There is no a priori reason why cells with receptors for certain hormones should respond to treatment with other hormones. But clearly in human breast cancer there may be many interactions between different hormones, including prolactin; and levodopa, a prolactin antagonist, has been used as a predictor of hormonal responsiveness. In two small studies"122 levodopa relieved bone pain in some patients, a positive result predicting response to subsequent endocrine ablation and correlating well with the presence of oestrogen receptors. Further trials are needed in suitable patients to see whether levodopa provides a useful test for patients in whom receptor assays are not done.

The place of hormone receptor assays in the routine management of metastatic breast cancer remains unsettled. Detecting oestrogen receptors can predict hormone responsiveness in $60^{\circ}{ }_{0}$ of ER-positive patients and prevent unnecessary surgical hormonal manipulations in receptor-negative patients. Against this we must weigh the cost and investment in facilities required to make assays generally available. Furthermore, if the primary use of non-surgical hormonal manoeuvres and more successful alternative systemic treatments become general in advanced breast cancer ablative surgical procedures would diminish in importance.

Despite this, assessment of ER state at the time of initial surgery would simplify the present-day management of many patients-the cost being somewhat offset by the avoidance of unnecessary surgery. As a future treatment, the use of cytotoxic agents linked to sex-steroid hormones remains a thoughtprovoking though unfulfilled possibility. ${ }^{1}$ Studies of hormonal receptors are now being extended to tumours other than breast cancer.

' Leclercq, G, and Heuson, J C, European fournal of Cancer, 1977, 13, 1205.

${ }^{2}$ Cikes, M, European Fournal of Cancer, 1978, 14, 211

${ }^{3}$ Korenman, S G, and Dukes, B A, fournal of Clinical Endocrinology, 1970, 30, 639.

4 Horwitz, K B, et al, Science, 1975, 189, 726.

${ }^{5}$ Maass, H, fournal of Steroid Biochemistry, 1975, 6, 743.

${ }^{6}$ EORTC Breast Cancer Group, European fournal of Cancer, 1973, 9, 379

' Jensen, E V, et al, in Estrogen Receptors in Human Breast Cancer, eds W I McGuire, P P Carbone, and E P Vollmer, p 37. New York, Raven Press, 1975.

${ }^{8}$ Wagner, R K, Hoppe-Seyler's Zeitschrift für Physiologische Chemie, 1972, $353,1235$. 